\title{
The Reduction in Duration of Antibiotic Therapy as a Key Element of Antibiotic Stewardship Programs
}

Pasquau $\mathbf{J}^{1^{*}}$, de Jesus ES ${ }^{1}$, Sadyrbaeva $\mathbf{S}^{2}$, Aznarte $\mathrm{P}^{2}$ and Hidalgo-Tenorio $\mathbf{C}^{1}$

${ }^{1}$ Infectious Diseases Services, Hospital Virgen de las Nieves, Granada, Spain

${ }^{2}$ Pharmacy Services, Hospital Virgen de las Nieves, Granada, Spain

\begin{abstract}
The incidence and mortality rates of severe infections are still very high. Moreover, the growing threat of bacterial resistance and the progressive reduction of research into new antibiotics, overshadows the future of the fight against infections. We need to preserve the effectiveness of available antibiotics. This can only be achieved if we minimize the development of bacterial resistance. We have sufficient evidence to show that reducing the duration of antibiotic treatment can minimize the potential development of bacterial resistance, without worsening the prognosis of infections. So, we think that the proposal to shorten the antibiotic treatment should become a key element of our antibiotic stewardship programs.
\end{abstract}

Keywords: Antibiotic optimization; Antibiotic de-escalation; Duration of antibiotic treatment; Antimicrobial stewardship programs

\section{Opinion}

\section{The progressive loss of antibiotic therapy efficacy}

Infection control has always seemed like something within our reach, but the truth is that the incidence and mortality rates associated with infections are still very high. Sepsis plays a part in one of two or three hospital deaths [1] and the mortality rates of severe infections are as high as $50 \%[2,3]$. The management of infectious diseases is always complex and the design of effective treatments is very difficult in many situations and for many physicians. Such is the case that there are many published studies that demonstrate how consulting an expert reduces infection-associated mortality rates $[4,5]$. However, this problem has become more complicated over the past few years as a consequence of antibiotic resistance, the progressive reduction of efficacy margins of available antibiotics and the lower availability of new antibiotics [6]. It is an alarming situation, that must be addressed with more institutional, and therefore, bureaucratic, political and social conviction.

\section{What can we do? On the way to a new antibiotic policy}

To ease this problem, one of the most important options, as far as healthcare professionals are concerned, is the optimization of antibiotic therapy. The development of an active antibiotic policy in healthcare centers, directed by a group of experts, that promotes an improvement of efficacy and a reduction of antibiotic resistance, is quite probably the main challenge an Infectious Disease specialist faces today [7-9].

Achieving a reduction of antibiotic exposure still remains the main objective of any antibiotic policy. There is a well-known relationship between the overall amount of antibiotic exposure and the development of bacterial resistance. It's a complex issue, but until now the main element of antibiotic policies in our hospitals was the reduction of exposure to better antibiotics (which were also the most expensive). This was carried out by restricting the access to their prescription and limiting their indications. This policy did not really consider the patient's prognosis and was frequently posed in dichotomous terms, focused on indication at the start of treatment. It never demonstrated any improvement other than economic savings, and it could theoretically cause a negative impact on antibiotic efficacy and severe infection prognosis. These new and expensive antibiotics that we try to restrict and protect against bacterial resistance, are also the most effective against severe infections when used as initial empirical treatment, at high doses or prolonged perfusions, and/or in combination therapy [10-26]. So insisting on their restriction in empiric therapy could be useless... and dangerous [27].

Therefore it's imperative to find a way to minimize exposure to antibiotics that does not compromise efficacy.

On the other hand, and in a different way than restrictive methods, the institutional attempt to use pedagogical consults as the only tool to achieve an adequate empiric antibiotic treatment for all infectious syndromes could also be useless and inefficient. Training activities are always needed, but have severe limitations to be applied in clinical practice.

\section{Antibiotic de-escalation and reduction in duration as a means to reduce antibiotic exposure}

We must be realistic and look for interventions and measures that are easier to transmit and easier for physicians to adopt. The scientific community is now accepting that a way of reducing antibiotic use is by adjusting the treatment after the third day, taking into account the antibiogram and the patient's clinical evolution. Early treatment suspension is also an option when the treatment has proven to be quickly effective, the patient has no severe immunodepression or difficult-to-treat microorganisms, bacterial reservoirs or biological sanctuaries with difficult access to antibiotics $[7,8,28]$.

This would mean a new paradigm in antibiotic therapy: intensive initial treatments with better options, focused on attaining optimal

*Corresponding author: MJuan Pasquau, Infectious Diseases Services, Complejo Hospitalario Universitario de Granada - Hospital Virgen de las Nieves, Granada, Spain, E-mail: jpasquau@gmail.com

Received December 14, 2015; Accepted December 21, 2015; Published December 30, 2015

Citation: Pasquau J, de Jesus ES, Sadyrbaeva S, Aznarte P, Hidalgo-Tenorio C (2015) The Reduction in Duration of Antibiotic Therapy as a Key Element of Antibiotic Stewardship Programs. J Antimicro 1: 103. doi:10.4172/2472 1212.1000103

Copyright: (c) 2015 Pasquau J, et al. This is an open-access article distributed under the terms of the Creative Commons Attribution License, which permits unrestricted use, distribution, and reproduction in any medium, provided the original author and source are credited. 
efficacy and better prognosis. When the patient has improved and we have microbiological results, those antibiotics can be switch for others with less ecological impact or costs and we can finally interrupt the treatment, earlier than we would have until now $[28,29]$.

These types of proposals are easier to accept by physicians that tend to hesitate to replace certain antibiotics, in which they trust, for others when treating a critical patient. Even though they accept their advantages in terms of ecological impact and costs, they feel these antibiotics are less safe [30]. It's easier to accept this proposal to replace, or even suspend, an antibiotic that has already proven its efficacy, the patient's situation has improved and there are no longer doubts about the patient's prognosis.

The only thing that's left if to find the arguments that can confirm that these exposure-reducing strategies (de-escalation and shortening of duration) are safe and do not compromise antibiotic therapy efficacy.

\section{Scientific arguments that support de-escalation and shortening of antibiotic therapy duration proposals}

Fortunately, the number of published studies that try to answer these questions has increased over the past year. They allow us to affirm the following aspects, with significant scientific evidence and for the type of patients previously mentioned (without immunosupression, difficult bacterial infections, antibiotic sanctuaries...):

1) The action and effect of antibiotics occur promptly, must be clinically visible after no longer than 3-4 days and must reach their maximum efficacy after no longer than 5-8 days, depending on the case. There are studies that demonstrate how fast bacteria disappear from the site of infection when they are sensitive to the antibiotics employed [31], as well as how fast inflammatory biomarkers decrease with an effective antibiotic treatment [32]. And last but not least, there are many clinical trials that demonstrate that the same clinical results can be achieved with both shortened and standard therapy strategies. There is no evidence that demonstrates that reducing the duration of antibiotic therapy, even as short as 3 days, leads to worse clinical results. It has been seen that when the evolution of inflammatory biomarkers, such as procalcitonin, is taken into account, antibiotic therapy suspension is safe, no matter how early on the suspension occurs [3337]. There is additional data that suggests that when the values of these biomarkers, especially procalcitonin, aren't elevated, treatment restraint or suspension is safe [38].

2) We refer to de-escalation as the switch from a broadspectrum antibiotic to a narrower spectrum agent or the reduction in the number of initially prescribed antibiotics [39-42]. It has proven to be a safe strategy and does not compromise efficacy, when compared to the sustained standard broad-spectrum empirical treatment $[43,44]$. When we adjust the antibiotic treatment based on the antibiogram, we're really just articulating the need for a pathogen-directed treatment. It's a concept that seems easy enough to transmit, assume and even demand. In order to conduct this treatment adjustment, a culture sample must be taken before empirical antibiotic treatment is initiated. This is an area we must continue to improve. However, de-escalation can also be an option when microbiology results are not available, as long as the patient's clinical condition has quickly improved, the inflammatory biomarkers have decreased significantly, and the variables mentioned before have been controlled. After all, de-escalation strategies support the idea that most of the antibiotic effect occurs during the first 3-5 days of treatment [32,45-48].
3) Unlike clinical efficacy, the induction of resistances to antibiotics is slower and increases over the time of exposure. The longer we maintain antibiotic treatment, the higher the possibility of encouraging and selecting antibiotic-resistant bacteria [49-56]. The other mechanism that causes an increase of resistance is the exposure to subtherapeutic concentrations of antibiotics [49-51,54-56]. This depends on pharmacodynamics, antibiotic activity, and the doses or strategies that are used. This was already described by Fleming shortly after discovering penicillin (Nobel lecture, 1945). We now have studies [49-56], both in vitro and in patients, during and after treatment, that search for changes in colonizing flora, and that show that these changes are associated with specific drugs, strategies and treatment duration. Finally, these publications support the idea that treatments that generate subtherapeutic concentrations at the site of infection and are maintained for longer periods of time have a higher potential for inducing resistance.

\section{Can these ideas be put into practice?}

These ideas are establishing a new paradigm of antibiotic therapy that consists of strong and short treatments. They have proven that we can improve antibiotic efficacy against severe infections. To do so, we must incorporate antibiotics with high antibacterial activity into empirical treatments and optimize their dosage to reach target concentrations at the site of infection [28]. These are what are now referred to as "front loading strategies" and "pharmacokinetic/pharmacodynamic (PK/PD) goals". Moreover, as well as increasing efficacy, this strategy reduces the emergence of bacterial resistance during treatment.

However, it is practically impossible to completely avoid the selection of resistant mutants. This selection can be observed after the first 3-4 days of exposure and becomes more intense as long as treatment persists [49-51]. Because of this, the reduction of duration of antibiotic therapy could be an important option to approach the bacterial resistance threat [53].

When we try to put these ideas into practice, the first step would probably be to reduce the duration of antibiotic therapy. This option is the easiest to include in our hospital's antibiotic policy [29]. In our experience, this proposal is accepted by at least $2 / 3$ of healthcare professionals at our hospital and it causes a quick and significant reduction of antibiotic exposure [57]. Physicians who actively participate in antibiotic stewardship programs have the responsibility of knowing, applying and spreading the knowledge that has been collected over the past few years on this subject.

\section{Proposals Summary about the short-course of antibiotherapy}

At present, we have enough scientific bases to support the following proposals:

A previous and important safety measure to consider is that the short-course of antibiotic therapy must not be applied to the following: patients with severe immunodepression, with severe infections and/ or infections produced my multidrug-resistant bacteria (MRSA, multidrug-resistant Pseudomonas spp or Acinetobacter spp), patients with a delay in surgical source control, with a prosthetic infection or with infections where antibiotic access is limited. Patients who haven't received an adequate initial treatment (poor design of antibiotherapy or by the presence of large inoculate, or particularly resistant or persistent bacteria) or who don't improve quickly must also be excluded. In these cases, the shortening of therapy must be considered with caution due to lack of evidence. 
Citation: Pasquau J, de Jesus ES, Sadyrbaeva S, Aznarte P, Hidalgo-Tenorio C (2015) The Reduction in Duration of Antibiotic Therapy as a Key Element of Antibiotic Stewardship Programs. J Antimicro 1: 103. doi: 10.4172/2472-1212.1000103

Page 3 of 6

Safety of therapy shortening has mostly been studied in respiratory diseases (excluding empyema and pulmonary abscess). We can conclude that:

- Community-acquired pneumonia can be treated with only 2-3 days after clinical improvement, and 5 days could be enough (as included in clinical guidelines) [58-66].

- Acute Chronic Obstructive Pulmonary Disease (CPOD) exacerbations can be treated for 5 days $[46,67,68]$.

- Ventilator-associated pneumonia (and bacterial tracheitis) should be treated for no longer than 8 days (as established in Cochrane Library recommendations) [69-73].

- ORL infections should be treated for no longer than 5-7 days (including strep throat if a cephalosporin is used instead of penicillin) $[74,75]$.

When it comes to other infectious diseases, we have less scientific evidence, but we can affirm that the following proposals are safe:

- $\quad$ Non-necrotizing skin infections: 5-10 days [76,77]

- Intraabdominal infections: 3-7 days [78-80]

- Uncomplicated UTI: $1-3$ days $[81,82]$

- $\quad$ Complicated, non-severe UTI: no longer than 7 days $[83,84]$

- Complicated, severe UTI: we should maintain the standard 2 week treatment because there is no data that supports treatment duration reduction. However, when fluorquinolones and carbapenems are used, we can reduce the duration to 7-10 days [85]. Any other treatments should still be administered for 10-15 days [86-88].

- Acute bacterial meningitis (caused by meningococcus or Haemophilus influenza) could be treated correctly for 7 days $[89,90]$. If it were caused by pneumococcus, there is less evidence about duration reduction, and it should probably be treated for 10-14 days [91]. Likewise, Listeria monocytogenes, Streptococcus agalactiae and gram-negative bacilli still may require 3 weeks of treatment.

- Septic Arthritis: For children, if the clinical response is good and the C-reactive protein level normalizes shortly, a treatment of 10 days is sufficient [92].

- Some experiences or reports, with very few patients, suggest that shorter treatments in patients with Bacteremia (7 days) $[93,94]$ or some kind of Endocarditis (14 days) [95-97] could be as effective as standard treatments.

There are also reviews $[72,98,99]$, guidelines $[66,80]$, meta-analysis and systematic reviews $[64,65,91,94]$ that show that the shortening of antibiotic therapy is a safe practice.

Finally, studies have shown that interventions to reduce the duration in antibiotic therapy are effective and lead to significant clinical benefits [57,100-102].

\section{Conclusions}

We have enough scientific evidence to affirm that we can safely shorten the duration of antibiotic therapy in a wide range of infections and patients. If we accomplish this, we'll be contributing to a reduction of bacterial resistance.

\section{References}

1. Liu V, Escobar GJ, Greene JD, Soule J, Whippy A, et al. (2014) Hospital deaths in patients with sepsis from 2 independent cohorts. JAMA 312: 90-92.

2. Kumar A, Ellis P, Arabi Y, Roberts D, Light B et al. (2009) Initiation of inappropriate antimicrobial therapy results in a fivefold reduction of survival in human septic shock. Chest 136: 1237-1248.

3. Rojas L, Bunsow E, Muñoz P, Cercenado E, Rodríguez-Créixems M,et al (2012) Vancomycin MICs do not predict the outcome of methicillin-resistant taphylococcus aureus bloodstream infections in correctly treated patients. J Antimicrob Chemother 67: 1760-1768.

4. Schmitt S, McQuillen DP, Nahass R, Martinelli L, Rubin M, et al. (2014) Infectious diseases specialty intervention is associated with decreased mortality and lower healthcare costs. Clin Infect Dis 58: 22-28.

5. Bai AD, Showler A, Burry L, Steinberg M, Ricciuto DR, et al. Impact of Infectious Disease Consultation on Quality of Care, Mortality, and Length of Stay in Staphylococcus aureus Bacteremia: Results From a Large Multicenter Cohort Study. Clin Infect Dis 60: 1451-1461.

6. Kollef MH, Guillamet CV (2015) If antibiotics did not exist. Intensive Care Med 41: 525-527.

7. Dellit TH, Owens RC, McGowan JE, Gerding DN, Weinstein RA, et al. (2007) Infectious Diseases Society of America and the Society for Healthcare Epidemiology of America guidelines for developing an institutional program to enhance antimicrobial stewardship. Clin Infect Dis 44: 159-177.

8. Rodríguez-Baño J, Paño-Pardo JR, Alvarez-Rocha L, Asensio Á, Calbo E, et al. (2012) [Programs for optimizing the use of antibiotics (PROA) in Spanish hospitals: GEIH-SEIMC, SEFH and SEMPSPH consensus document]. Farm Hosp 36: 33.e1-0.

9. Bartlett JG, Gilbert DN, Spellberg B (2013) Seven ways to preserve the miracle of antibiotics. Clin Infect Dis 56: 1445-1450.

10. Moore CL, Osaki-Kiyan P, Haque NZ, Perri MB, Donabedian S, et al. (2012) Daptomycin versus vancomycin for bloodstream infections due to methicillinresistant Staphylococcus aureus with a high vancomycin minimum inhibitory concentration: a case-control study. Clin Infect Dis 54: 51-58.

11. Weston A, Boucher HW (2012) Daptomycin for methicillin-resistant Staphylococcus aureus bloodstream infection and elevated vancomycin minimum inhibitory concentrations: has the time come? Clin Infect Dis 54: 5961.

12. Murray KP, Zhao JJ, Davis SL, Kullar R, Kaye KS, et al. (2013) Early use of daptomycin versus vancomycin for methicillin-resistant Staphylococcus aureus bacteremia with vancomycin minimum inhibitory concentration $>1 \mathrm{mg} / \mathrm{L}$ : a matched cohort study. Clin Infect Dis 56: 1562-1569.

13. Caffrey AR, Morrill HJ, Puzniak LA, Laplante KL (2014) Comparative effectiveness of linezolid and vancomycin among a national veterans affairs cohort with methicillin-resistant Staphylococcus aureus pneumonia Pharmacotherapy 34: 473-480.

14. Edwards SJ, Clarke MJ, Wordsworth S, Welton NJ (2009) Carbapenems versus other beta-lactams in the treatment of hospitalised patients with infection: a mixed treatment comparison. Curr Med Res Opin 25: 251-261.

15. Lee NY, Lee CC, Huang WH, Tsui KC, Hsueh PR, et al. (2015) Cefepime therapy for monomicrobial bacteremia caused by cefepime-susceptible extendedspectrum beta-lactamase-producing Enterobacteriaceae: MIC matters. Clin Infect Dis 56: 488-495

16. Tam VH, Gamez EA, Weston JS, Gerard LN, Larocco MT, et al. (2008) Outcomes of bacteremia due to Pseudomonas aeruginosa with reduced susceptibility to piperacillin-tazobactam: implications on the appropriateness of the resistance breakpoint. Clin Infect Dis 46: 862-867.

17. Vardakas KZ, Tansarli GS, Rafailidis PI, Falagas ME (2012) Carbapenems versus alternative antibiotics for the treatment of bacteraemia due to Enterobacteriaceae producing extended-spectrum $\beta$-lactamases: a systematic review and meta-analysis. J Antimicrob Chemother 67: 2793-2803.

18. Taccone FS, Laterre PF, Dugernier T, Spapen H, Delattre I, et al. (2010) 
Citation: Pasquau J, de Jesus ES, Sadyrbaeva S, Aznarte P, Hidalgo-Tenorio C (2015) The Reduction in Duration of Antibiotic Therapy as a Key Element of Antibiotic Stewardship Programs. J Antimicro 1: 103. doi: 10.4172/2472-1212.1000103

Page 4 of 6

Insufficient $\beta$-lactam concentrations in the early phase of severe sepsis and septic shock. Crit Care 14:R126.

19. Tamma PD, Han JH, Rock C, Harris AD, Lautenbach E, et al. (2015) Carbapenem therapy is associated with improved survival compared with piperacillin-tazobactam for patients with extended-spectrum $\beta$-lactamase bacteremia. Clin Infect Dis 60: 1319-1325.

20. Frei CR, Wiederhold NP, Burgess DS (2008) Antimicrobial breakpoints for gram-negative aerobic bacteria based on pharmacokinetic-pharmacodynamic models with Monte Carlo simulation. J Antimicrob Chemother 61: 621-628.

21. Tumbarello $M$, Viale $P$, Viscoli $C$, Trecarichi EM, Tumietto $F$, et al. Predictors of mortality in bloodstream infections caused by Klebsiella pneumoniae carbapenemase-producing K. pneumoniae: importance of combination therapy. Clin Infect Dis 55: 943-50.

22. Zarkotou O, Pournaras S, Tselioti P, Dragoumanos V, Pitiriga V, et al. (2011) Predictors of mortality in patients with bloodstream infections caused by KPC producing Klebsiella pneumoniae and impact of appropriate antimicrobial treatment. Clin Microbiol Infect. 17: 1798-1803.

23. Qureshi ZA, Hittle LE, O'Hara JA, Rivera JI, Syed A, et al. (2015) Colistinresistant Acinetobacter baumannii: beyond carbapenem resistance. Clin Infect Dis 60: $1295-1303$.

24. Drusano GL, Liu W, Fregeau C, Kulawy R, Louie A (2009) Differing effects of combination chemotherapy with meropenem and tobramycin on cell kill and suppression of resistance of wild-type Pseudomonas aeruginosa PAO1 and its isogenic MexAB efflux pump-overexpressed mutant. Antimicrob Agents Chemother 53: 2266-2273.

25. Drusano GL, Louie A, Deziel M, Gumbo T (2006) The crisis of resistance: identifying drug exposures to suppress amplification of resistant mutant subpopulations. Clin Infect Dis 42: 525-532.

26. Dulhunty JM, Roberts JA, Davis JS, Webb SA, Bellomo R, et al. Continuous infusion of beta-lactam antibiotics in severe sepsis: a multicenter double-blind randomized controlled trial. Clin Infect Dis. 2013;56(2):236-44.

27. Leibovici L, Paul M, Ezra O (2012) Ethical dilemmas in antibiotic treatment. $J$ Antimicrob Chemother 67: 12-16.

28. Dryden M, Johnson AP, Ashiru-Oredope D, Sharland M (2011) Using antibiotics responsibly: right drug, right time, right dose, right duration. J Antimicrob Chemother 66: 2441-2443.

29. Rice LB (2008) The Maxwell Finland Lecture: for the duration-rational antibiotic administration in an era of antimicrobial resistance and clostridium difficile. Clin Infect Dis 46: 491-496.

30. Calbo E, Alvarez-Rocha L, Gudiol F, Pasquau J (2013) A review of the factors influencing antimicrobial prescribing. Enferm Infecc Microbiol Clin 31 Supp 4:12-5.

31. Montravers P, Fagon JY, Chastre J, Lecso M, Dombret MC, et al. (1993) Followup protected specimen brushes to assess treatment in nosocomial pneumonia. Am Rev Respir Dis 147: 38-44.

32. Luna CM, Blanzaco D, Niederman MS, Matarucco W, Baredes NC, et al. (2003) Resolution of ventilator-associated pneumonia: prospective evaluation of the clinical pulmonary infection score as an early clinical predictor of outcome. Crit Care Med 31: 676-682.

33. Nobre V, Harbarth S, Graf JD, Rohner P, Pugin J (2008) Use of procalcitonin to shorten antibiotic treatment duration in septic patients: a randomized trial. Am J Respir Crit Care Med 177: 498-505.

34. Agarwal R, Schwartz DN (2011) Procalcitonin to guide duration of antimicrobia therapy in intensive care units: a systematic review. Clin Infect Dis $53: 379-387$.

35. Hochreiter M, Köhler T, Schweiger AM, Keck FS, Bein B, et al. (2009) Procalcitonin to guide duration of antibiotic therapy in intensive care patients: a randomized prospective controlled trial. Crit Care 13: R83.

36. Schuetz P, Christ-Crain M, Thomann R, Falconnier C, Wolbers M, et al. (2009) Effect of procalcitonin-based guidelines vs standard guidelines on antibiotic use in lower respiratory tract infections: the ProHOSP randomized controlled trial. JAMA 302: 1059-1066

37. Póvoa P, Coelho L, Almeida E, Fernandes A, Mealha R, et al. (2005) Pilot study evaluating $\mathrm{C}$-reactive protein levels in the assessment of response to treatment of severe bloodstream infection. Clin Infect Dis 40: 1855-1857.
38. Burkhardt O, Ewig S, Haagen U, Giersdorf S, Hartmann O, et al. (2010) Procalcitonin guidance and reduction of antibiotic use in acute respiratory tract infection. Eur Respir J 36: 601-607.

39. Camargo LF (2013) The "De-escalation Concept" and Antibiotic De-escalation: A Missed Opportunity?. Shock 39: 29-31.

40. Masterton RG (2011) Antibiotic de-escalation. Crit Care Clin 27: 149-162.

41. Garnacho-Montero J, Escoresca-Ortega A, Fernández-Delgado E (2015) Antibiotic de-escalation in the ICU: how is it best done? Curr Opin Infect Dis 28: 193-8.

42. Rello J, Vidaur L, Sandiumenge A, Rodríguez A, Gualis B, et al. (2004) Deescalation therapy in ventilator-associated pneumonia. Crit Care Med 32 2183-2190.

43. Garnacho-Montero J, Gutiérrez-Pizarraya A, Escoresca-Ortega A, CorciaPalomo Y, Fernández-Delgado E, et al. (2014) De-escalation of empirical therapy is associated with lower mortality in patients with severe sepsis and septic shock. Intensive Care Med 40: 32-40.

44. Leone M, Bechis C, Baumstarck K, Lefrant JY, Albanèse J, et al. (2014) Deescalation versus continuation of empirical antimicrobial treatment in severe sepsis: a multicenter non-blinded randomized noninferiority trial. Intensive Care Med 40: 1399-1408.

45. Awunor-Renner C (1979) Length of antibiotic therapy in in-patients with primary pneumonias. Ann Trop Med Parasitol 73: 235-240.

46. Miravitlles M, Ros F, Cobos A, Kubin R, Tillotson G (2001) The efficacy of moxifloxacin in acute exacerbations of chronic bronchitis: a Spanish physician and patient experience. Int J Clin Pract 55: 437-441.

47. Forrest A, Nix DE, Ballow CH, Goss TF, Birmingham MC, et al. (1993) Pharmacodynamics of intravenous ciprofloxacin in seriously ill patients. Antimicrob Agents Chemother. 37: 1073-1081.

48. Vidaur L, Planas K, Sierra R, Dimopoulos G, Ramirez A, et al. (2008) Ventilatorassociated pneumonia: impact of organisms on clinical resolution and medical resources utilization. Chest 133: 625-632.

49. Thomas JK, Forrest A, Bhavnani SM, Hyatt JM, Cheng A, et al. (1998) Pharmacodynamic evaluation of factors associated with the development of bacterial resistance in acutely ill patients during therapy. Antimicrob Agents Chemother. 42: 521-527.

50. Drlica K, Zhao X (2007) Mutant selection window hypothesis updated. Clin Infect Dis 44: 681-688.

51. Tam VH, Louie A, Fritsche TR, Deziel M, Liu W, et al. (2007) Impact of drugexposure intensity and duration of therapy on the emergence of Staphylococcus aureus resistance to a quinolone antimicrobial. J Infect Dis 195: 1818-1827.

52. Smirnova MV, Vostrov SN, Strukova EV, Dovzhenko SA, Kobrin MB, et al (2009) The impact of duration of antibiotic exposure on bacterial resistance predictions using in vitro dynamic models. J Antimicrob Chemother 64: 815820

53. D’Agata EM, Magal P, Olivier D, Ruan S, Webb GF (2007) Modeling antibiotic resistance in hospitals: the impact of minimizing treatment duration. $\mathrm{J}$ Theo Biol 249: 487-499.

54. Guillemot D, Carbon C, Balkau B, Geslin P, Lecoeur H, et al. (1998) Low dosage and long treatment duration of beta-lactam: risk factors for carriage of penicillin-resistant Streptococcus pneumoniae. JAMA 279: 365-370.

55. Schrag SJ, Peña C, Fernández J, Sánchez J, Gómez V, et al. (2001) Effect of short-course, high-dose amoxicillin therapy on resistant pneumococcal carriage: a randomized trial. JAMA 286: 49-56

56. Hillier S, Roberts Z, Dunstan F, Butler C, Howard A, et al. (2007) Prior antibiotics and risk of antibiotic-resistant community-acquired urinary tract infection: a case-control study. J Antimicrob Chemother 60: 92-99.

57. Pasquau J, Aznarte P, Hidalgo C, Rojo MD, Castaño J, et al. (2013) Del control sobre la prescripción de antibióticos al control de la duración de la antibioterapia: un viaje hacia la efectividad en la reducción de la exposición a antibióticos. XVII Congreso de la Sociedad Española de Enfermedades Infecciosas y Microbiología Clínica Zaragoza, España: Enf Infecc Microbio Clin 31: 54.

58. Dunbar LM, Wunderink RG, Habib MP, Smith LG, Tennenberg AM, et al. (2003) 
Citation: Pasquau J, de Jesus ES, Sadyrbaeva S, Aznarte P, Hidalgo-Tenorio C (2015) The Reduction in Duration of Antibiotic Therapy as a Key Element of Antibiotic Stewardship Programs. J Antimicro 1: 103. doi: 10.4172/2472-1212.1000103

Page 5 of 6

High-dose, short-course levofloxacin for community-acquired pneumonia: a new treatment paradigm. Clin Infect Dis 37: 752-760.

59. Shorr AF, Zadeikis N, Xiang JX, Tennenberg AM, Wes Ely E (2005)A multicenter, randomized, double-blind, retrospective comparison of 5- and 10-day regimens of levofloxacin in a subgroup of patients aged $>$ or $=65$ years with communityacquired pneumonia. Clin Ther 27: 1251-1259.

60. File TM, Mandell LA, Tillotson G, Kostov K, Georgiev O (2007) Gemifloxacin once daily for 5 days versus 7 days for the treatment of community-acquired pneumonia: a randomized, multicentre, double-blind study. J Antimicrob Chemother 60: 112-120.

61. Agarwal G, Awasthi S, Kabra SK, Kaul A, Singhi S, et al. (2004) Three day versus five day treatment with amoxicillin for non-severe pneumonia in young children: a multicentre randomised controlled trial. BMJ 328: 791.

62. el Moussaoui R, de Borgie CA, van den Broek P, Hustinx WN, Bresser P, et al. (2006) Effectiveness of discontinuing antibiotic treatment after three days versus eight days in mild to moderate-severe community acquired pneumonia: randomised, double blind study. BMJ 332: 1355

63. O'Doherty B, Muller O (1998) Randomized, multicentre study of the efficacy and tolerance of azithromycin versus clarithromycin in the treatment of adults with mild to moderate community-acquired pneumonia. Azithromycin Study Group. Eur J Clin Microbiol Infect Dis 17: 828-833.

64. Dimopoulos G, Matthaiou DK, Karageorgopoulos DE, Grammatikos AP Athanassa Z, et al. (2008) Short- versus long-course antibacterial therapy for community-acquired pneumonia : a meta-analysis. Drugs 68: 1841-1854.

65. Scalera NM, File TM (2013) Determining the duration of therapy for patients with community-acquired pneumonia. Curr Infect Dis Rep 15: 191-195.

66. Mandell LA, Wunderink RG, Anzueto A, Bartlett JG, Campbell GD, et al. (2007) Infectious Diseases Society of America/American Thoracic Society consensus guidelines on the management of community-acquired pneumonia in adults. Clin Infect Dis 44: S27-S72.

67. Grossman RF, Ambrusz ME, Fisher AC, Khashab MM, Kahn JB (2006) levofloxacin $750 \mathrm{mg}$ QD for five days versus amoxicillin/clavulanate 875 $\mathrm{mg} / 125 \mathrm{mg}$ BID for ten days for treatment of acute bacterial exacerbation of chronic bronchitis: a post hoc analysis of data from severely ill patients. Clin Ther 28: 1175-1180.

68. Roede BM, Bresser P, El Moussaoui R, Krouwels FH, van den Berg BT, et al. (2007) Three vs. 10 days of amoxycillin-clavulanic acid for type 1 acute exacerbations of chronic obstructive pulmonary disease: a randomised double-blind study. Clin Microbiol Infect 13: 284-290.

69. Chastre J, Wolff M, Fagon JY, Chevret S, Thomas F, et al. (2003) Comparison of 8 vs 15 days of antibiotic therapy for ventilator-associated pneumonia in adults: a randomized trial. JAMA 290: 2588-2598.

70. Micek ST, Ward S, Fraser VJ, Kollef MH (2004) A randomized controlled trial of an antibiotic discontinuation policy for clinically suspected ventilator-associated pneumonia. Chest 125: 1791-1799.

71. Singh N, Rogers P, Atwood CW, Wagener MM, Yu VL (2000) Short-course empiric antibiotic therapy for patients with pulmonary infiltrates in the intensive care unit. A proposed solution for indiscriminate antibiotic prescription. Am J Respir Crit Care Med 162: 505-511.

72. Pugh R, Grant C, Cooke RP, Dempsey G (2015) Short-course versus prolongedcourse antibiotic therapy for hospital-acquired pneumonia in critically ill adults. Cochrane Database Syst Rev 8: CD007577.

73. Tamma PD, Turnbull AE, Milstone AM, Lehmann CU, Sydnor ER, et al. (2011) Ventilator-associated tracheitis in children: does antibiotic duration matter? Clin Infect Dis 52: 1324-1331.

74. Jones R, Bain J (1986) Three-day and seven-day treatment in acute otitis media: a double-blind antibiotic trial. J R Coll Gen Pract 36: 356-358.

75. Casey JR, Pichichero ME (2005) Metaanalysis of short course antibiotic treatment for group a streptococcal tonsillopharyngitis. Pediatr Infect Dis J 24: 909-917.

76. Hepburn MJ, Dooley DP, Skidmore PJ, Ellis MW, Starnes WF, et al. (2004) Comparison of short-course (5 days) and standard (10 days) treatment for uncomplicated cellulitis. Arch Intern Med 164: 1669-1674.

77. Ruhe JJ, Smith N, Bradsher RW, Menon A (2007) Community-onset methicillin- resistant Staphylococcus aureus skin and soft-tissue infections: impact of antimicrobial therapy on outcome. Clin Infect Dis 44: 777-784.

78. Schug-Pass C, Geers P, Hügel O, Lippert H, Köckerling F (2010) Prospective randomized trial comparing short-term antibiotic therapy versus standard therapy for acute uncomplicated sigmoid diverticulitis. Int J Colorectal Dis 25 751-759.

79. Catena F, Vallicelli C, Ansaloni L, Sartelli M, Di Saverio S, et al. T.E.A Study: three-day ertapenem versus three-day Ampicillin-Sulbactam. BMC Gastroenterol 13: 76

80. Solomkin JS, Mazuski JE, Bradley JS, Rodvold KA, Goldstein EJ, et al. (2010) Diagnosis and management of complicated intra-abdominal infection in adults and children: guidelines by the Surgical Infection Society and the Infectious Diseases Society of America. Surg Infect (Larchmt) 11: 79-109.

81. Backhouse Cl, Matthews JA (1989) Single-dose enoxacin compared with 3-day treatment for urinary tract infection. Antimicrob Agents Chemother 33: 877-880.

82. Arredondo-García JL, Figueroa-Damián R, Rosas $A$, Jáuregui $A$, Corral $M$, et al. (2004) Comparison of short-term treatment regimen of ciprofloxacin versus long-term treatment regimens of trimethoprim/sulfamethoxazole or norfloxacin for uncomplicated lower urinary tract infections: a randomized, multicentre, open-label, prospective study. J Antimicrob Chemother 54: 840-843.

83. Drekonja DM, Rector TS, Cutting A, Johnson JR (2013) Urinary tract infection in male veterans: treatment patterns and outcomes. JAMA Intern Med 173: 62-68.

84. Keren R, Chan E (2003) Short versus standard duration antibiotic treatment for UTIs: a comparison of two meta-analyses. Arch Dis Child 88: 89-91.

85. Sandberg T, Skoog G, Hermansson AB, Kahlmeter G, Kuylenstierna N et al. (2012) Ciprofloxacin for 7 days versus 14 days in women with acute pyelonephritis: a randomised, open-label and double-blind, placebo-controlled non-inferiority trial. Lancet 380: 484-490.

86. Kyriakidou KG, Rafailidis P, Matthaiou DK, Athanasiou S, Falagas ME (2008) Short- versus long-course antibiotic therapy for acute pyelonephritis in adolescents and adults: a meta-analysis of randomized controlled trials. Clin Ther 30: 1859-1868.

87. Peterson J, Kaul S, Khashab M, Fisher AC, Kahn JB (2008) A double-blind randomized comparison of levofloxacin $750 \mathrm{mg}$ once-daily for five days with ciprofloxacin $400 / 500 \mathrm{mg}$ twice-daily for 10 days for the treatment of complicated urinary tract infections and acute pyelonephritis. Urology 71: 17-22.

88. Naber KG, Llorens L, Kaniga K, Kotey P, Hedrich D,et al. (2009) Intravenous doripenem at 500 milligrams versus levofloxacin at 250 milligrams, with an option to switch to oral therapy, for treatment of complicated lower urinary tract infection and pyelonephritis. Antimicrob Agents Chemother 53: 3782-3792.

89. Ellis-Pegler R, Galler L, Roberts S, Thomas M, Woodhouse A (2003) Three days of intravenous benzyl penicillin treatment of meningococcal disease in adults. Clin Infect Dis 37: 658-662.

90. Molyneux E, Nizami SQ, Saha S, Huu KT, Azam M, et al. (2011) 5 versus 10 days of treatment with ceftriaxone for bacterial meningitis in children: a doubleblind randomised equivalence study. Lancet 377: 1837-1845

91. Karageorgopoulos DE, Valkimadi PE, Kapaskelis A, Rafailidis PI, Falagas ME (2009) Short versus long duration of antibiotic therapy for bacterial meningitis: a meta-analysis of randomised controlled trials in children. Arch Dis Child 94 607-614.

92. Peltola H, Pääkkönen M, Kallio P, Kallio MJ, Group O-SAO-SS (2009) Prospective, randomized trial of 10 days versus 30 days of antimicrobial treatment, including a short-term course of parenteral therapy, for childhood septic arthritis. Clin Infect Dis 48: 1201-1210.

93. Corona A, Wilson AP, Grassi M, Singer M (2004) Prospective audit of bacteraemia management in a university hospital ICU using a general strategy of short-course monotherapy. J Antimicrob Chemother 54: 809-817.

94. Havey TC, Fowler RA, Daneman N (2011) Duration of antibiotic therapy for bacteremia: a systematic review and meta-analysis. Crit Care 15: R267.

95. DiNubile MJ (1994) Short-course antibiotic therapy for right-sided endocarditis caused by Staphylococcus aureus in injection drug users. Ann Intern Med 121 873-876.

96. Shanson DC (1998) New guidelines for the antibiotic treatment of streptococcal 
Citation: Pasquau J, de Jesus ES, Sadyrbaeva S, Aznarte P, Hidalgo-Tenorio C (2015) The Reduction in Duration of Antibiotic Therapy as a Key Element of Antibiotic Stewardship Programs. J Antimicro 1: 103. doi: 10.4172/2472-1212.1000103

enterococcal and staphylococcal endocarditis. J Antimicrob Chemother 42: 292-296.

97. Morris AJ, Drinković D, Pottumarthy S, MacCulloch D, Kerr AR, et al. (2012) Bacteriological outcome after valve surgery for active infective endocarditis: implications for duration of treatment after surgery. Clin Infect Dis 41: 187-194.

98. Altamimi S, Khalil A, Khalaiwi KA, Milner RA, Pusic MV, et al. Short-term lategeneration antibiotics versus longer term penicillin for acute streptococcal pharyngitis in children. Cochrane Database Syst Rev 8: CD004872.

99. Hayashi Y, Paterson DL (2012) Strategies for reduction in duration of antibiotic use in hospitalized patients. Clin Infect Dis 52: 1232-1240.
100. Avdic E, Cushinotto LA, Hughes AH, Hansen AR, Efird LE, et al. (2012) Impact of an antimicrobial stewardship intervention on shortening the duration of therapy for community-acquired pneumonia. Clin Infect Dis 54: 1581-1587.

101. Marra AR, de Almeida SM, Correa L, Silva M, Martino MD, et al. (2009) The effect of limiting antimicrobial therapy duration on antimicrobial resistance in the critical care setting. Am J Infect Control 37: 204-209.

102. Nicasio AM, Eagye KJ, Kuti EL, Nicolau DP, Kuti JL (2010) Length of stay and hospital costs associated with a pharmacodynamic-based clinical pathway for empiric antibiotic choice for ventilator-associated pneumonia. Pharmacotherapy 30: 453-462. 